and D. George (eds.)

\title{
A new species of Pista (Annelida: Polychaeta: Terebellidae) from shallow waters of Shizugawa Bay, Sanriku Coast, Japan.
}

\author{
EIJIROH NISHI ${ }^{1}$ and KATSUHIKO TANAKA ${ }^{2}$ \\ ${ }^{1}$ Manazuru Marine Laboratory for Science Education, Yokohama National University, Iwa, Manazuru, Kanagawa 259- \\ 0202, Japan E-mail: enishi@ynu.ac.jp \\ ${ }^{2}$ Shizugawa Nature Centre, Shizugawa, Miyagi 986-0781, Japan
}

\begin{abstract}
SUMMARY: A new species of the genus Pista (Annelida: Polychaeta: Terebellidae) was found on a boulder bottom in shallow waters of of Shizugawa Bay, Sanriku coast, northern Honshu, Japan. Individuals of this species measure 5 to $10 \mathrm{~cm}$ long and 3 to $5 \mathrm{~mm}$ wide. There are two pairs of branchiae on segments 2 and 3, each with an annulated long stalk and many dichotomous branches. The peristomium and segment 3 have elongate, semi-circular lateral lobes, segments 2 and 4 each have small lobes, segments 5 and 6 have very small lobes inserted between the neuropodium and ventral pad. Individuals of the new species have 17 pairs of notopodia from segment 4 and conical nephridial papillae on segments 6 and 7 . The new Japanese species differs from all known species in the structure of the branchiae and the lateral lobes of anterior chaetigers.
\end{abstract}

Keywords: Polychaeta, Shizugawa, Tohoku, Pista, new species, Terebellidae, taxonomy.

RESUMEN: Una nueva especie de Pista (Annelida: Polychaeta: Terebellidae) De aguas someras de la Bahía de Shizugawa, Costa de SANRIKu (JAPÓN). - Una nueva especie de Pista (Annelida: Polychaeta: Terebellidae) fue encontrada en fondos someros de cantos rodados de la Bahía de Shizugawa, Costa de Sanriku (Norte de Honshu, Japón). Los individuos de esta nueva especie miden de 5 a $10 \mathrm{~cm}$ de largo y de 3 a $5 \mathrm{~mm}$ de ancho. Presentan 2 pares de branquias en los segmentos 2 y 3 , cada uno con un largo pedúnculo anulado y ramas dicotómicas. El peristomio y el segmento 3 presentan lóbulos laterales elongados y semicirculares, los segmentos 2 y 4 presentan lóbulos pequeños y los segmentos 5 y 6 lóbulos muy pequeños insertados entre el neuropodio y la zona ventral. Los individuos de la nueva especie tienen 17 pares de notopodia, desde el segmento 4, y papilas nefridiales cónicas en los segmentos 6 y 7. La nueva especie difiere de las especies conocidas en la estructura de las branquias y los lóbulos de los setígeros anteriores.

Palabras clave: Polychaeta, Shizugawa, Tohoku, Pista, nueva especie, Terebellidae, taxonomia.

\section{INTRODUCTION}

We have studied the terebellids from Shizugawa Bay, Sanriku coast, Tohoku region, northern Honshu, Japan (Fig. 1). We collected eight species of the family, of which three or four species are probably new to Japan, and one species is new to science. We report here on the new taxon of Terebellidae from the shallow water of Shizugawa Bay, Japan.
Seven species of Pista have been recorded from Japanese waters: P. atypica Hessle, 1917; P. cristata (Muller, 1776); P. elongata Moore, 1909; P. fasciata sensu Marenzeller, 1885; P. fasciata sensu MacIntosh, 1885; P. microlobata Hessle, 1917; P. robustiseta Caullery, 1915 (Imajima and Hartman, 1964; Uchida, 1992). These records and descriptions are brief and provide limited information on the features distinguishing these species. A revision of the Japanese species is required. 


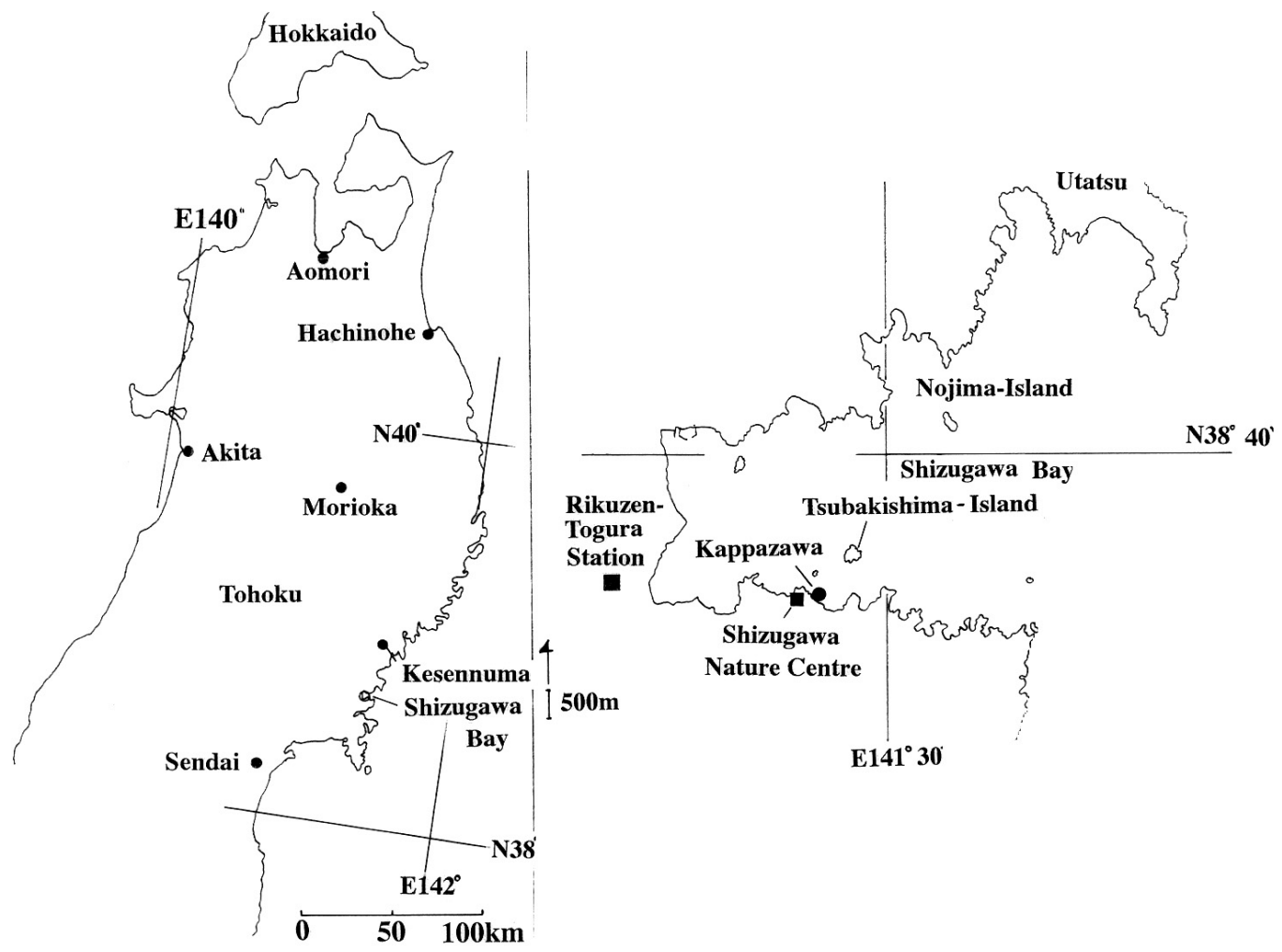

FIG. 1. - Map of Shizugawa Bay and Tohoku region (left) and map of Shizugawa Bay and collection site (Kappazawa)(right).

The genus Pista Malmgren, 1866 has been revised by Hutchings (1977), Hutchings and Glasby (1988) and Hutchings (1990). We have expanded their generic diagnosis of Pista (Hutchings and Glasby, 1988) to include species with lateral lobes on segments 2-6 and describe a new species, and compare this with previously described species from Japan and the Pacific.

\section{MATERIALS AND METHODS}

Terebellid polychaetes were collected by hand using SCUBA in depths of $10 \mathrm{~m}$ on boulder bottoms. The worms were collected from the underside of stones where the tubes were attached, and were transported to the laboratory. Animals were fixed in $10 \%$ neutralized formaldehyde and subsequently transferred to $70 \%$ ethanol. Two specimens were transferred through an ethanol series and butylalcohol, freeze dried using a Hitachi ES-2030 Freeze Dryer, coated with palladium by an Hitachi E-1010 Ion Sputterer, and observed on a Hitachi SEM S-3000N scanning electron microscope. Notochaetae and neurochaetae from the paratypes were permanently mounted on to slides for detailed examination.
Material of the new species is deposited in the following museums:

USNM, United States National Museum, Smithsonian Institution, Washington, DC,USA.

AHF-LACM, Allan Hancock Foundation Polychaete Collection, Los Angeles County Museum, California, USA.

AM, Australian Museum, Sydney, Australia

$\mathrm{CMNH}$, Coastal Branch of the Natural History Museum and Institute, Chiba, Katsuura, Chiba Prefecture, Japan

NHM, The Natural History Museum, London, UK

SAM, South Australian Museum, Adelaide, Australia

SMF, Senckenberg Museum, Frankfurt, Germany

ZMUC Zoological Museum, University of Copenhagen, Copenhagen, Denmark.

\section{SYSTEMATICS}

Genus Pista Malmgren,1866 emended

Diagnosis. Lateral lobes on segments 2-4 or 2-6; and sometimes on peristomium. Branchiae 1-3 
pairs. Other characters are the same as in the Hutchings and Glasby (1988)definition.

Remarks. We have expanded the generic diagnosis of Pista to include species with lateral lobes on segments 2-6. Previously, the genus was regarded as having lateral lobes on segments 2-4 (Hutchings, 1977; Hutchings and Glasby, 1988). Hutchings and Glasby (1988) suggested that several groups exist in the genus. The species having lateral lobes on segments 2-6 reported herein belongs to a group previously unknown. Except for the distribution of lateral lobes of anterior chaetigers, however, other features of this species indicate that it belongs to the genus Pista.

Pista shizugawaensis n. sp. (Figs 2-4)

Material examined. Holotype - CMNH-ZW01800 Kappazawa, Shizugawa Bay, Miyagi, Japan, collected by K. Tanaka, 14 August, 2003. Paratypes, collection site and collector are the same as for the
holotype:AM-W29405, 14 Aug 2003, SMF 15178, 11 June 2003; NHM-2005.1516, 14 August, 2003; USNM-1078490, 7 May, 2003; SAM-E3457, 14 August, 2003; ZMUC-POL-1851, 11 June 2003; LACM-AHF-POLY 2170, 7 May, 2003. Non-type material, collection site and collector are the same as for the holotype: CMNHZW01798, on SEM stub.

Description. Preserved body brown to pale brown, in life light brown to light yellow. Body length 50 to $150 \mathrm{~mm}$, thoracic width 1.5 to $4.0 \mathrm{~mm}$, abdominal width 0.5 to $2.0 \mathrm{~mm}$. Buccal tentacles numerous, arising from thickened glandular margin (Figs 2A, 4A). Prostomium compact with anteriorly projecting "tongue", glandular with convoluted margins. Eye spots absent. Peristomium thickened, with large lateral semi-circular lobes connected by a Ushaped thickened ridge (Fig. 2A, B, C).

Branchiae 2 pairs on segments 2 and 3 , each pair consisting of equal- (NHM-2005.1516) or unequalsized branchiae (ZMUC-POL 1851), largest on segment 2 and smallest on segment 3 (SMF-15178) or largest on segment 3 and smallest on segment 2 (SAM E3457) (Fig. 2A). Branchial stalk stout with
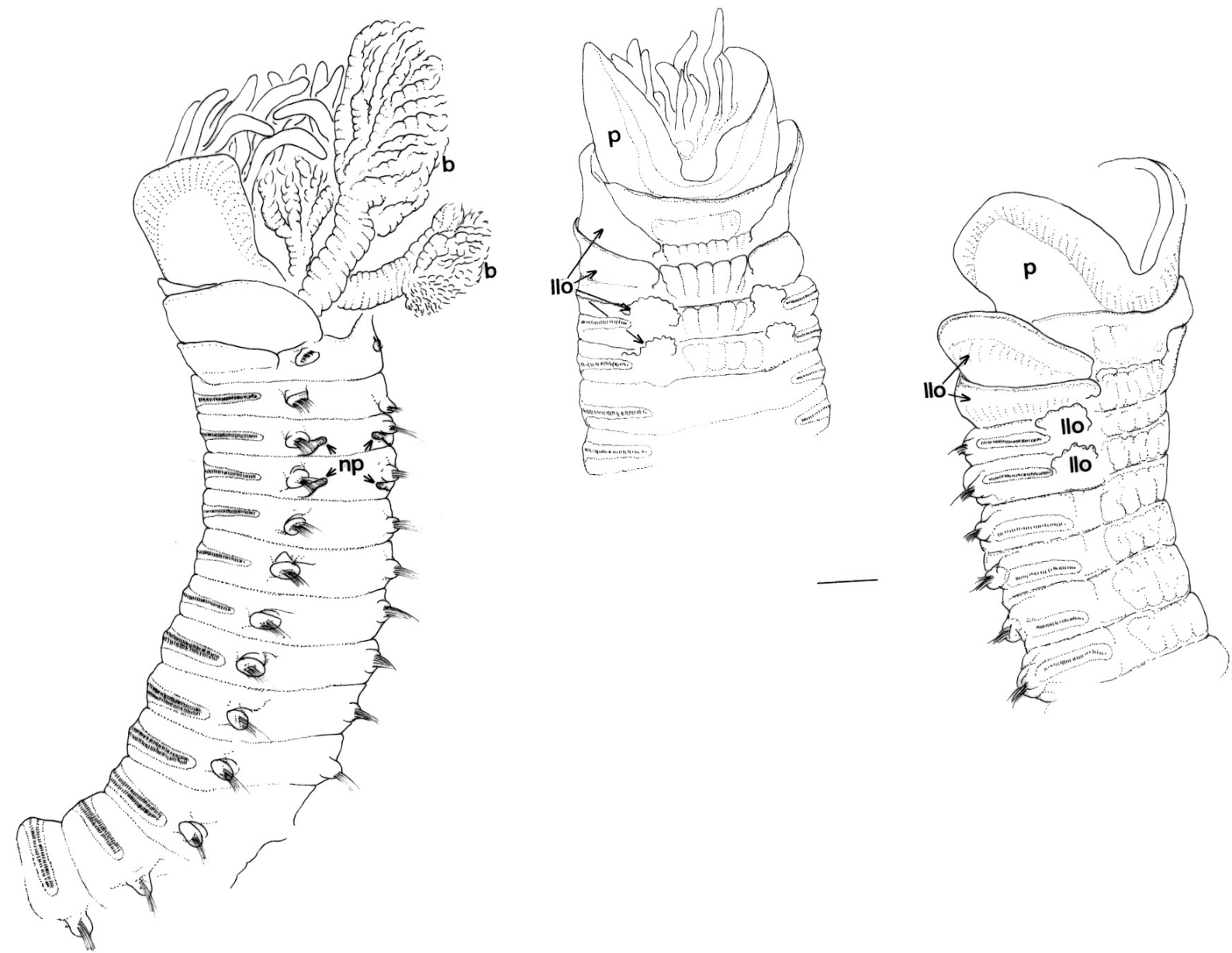

FIG. 2. - Anterior part of Pista shizugawaensis n. sp. (SAM E3457). A, dorso-lateral view. B, ventral view. C, ventro-lateral view. b, branchia. llo, lateral lobe. np, nephridial papillae. p, peristomium. Scale is $1 \mathrm{~mm}$. 


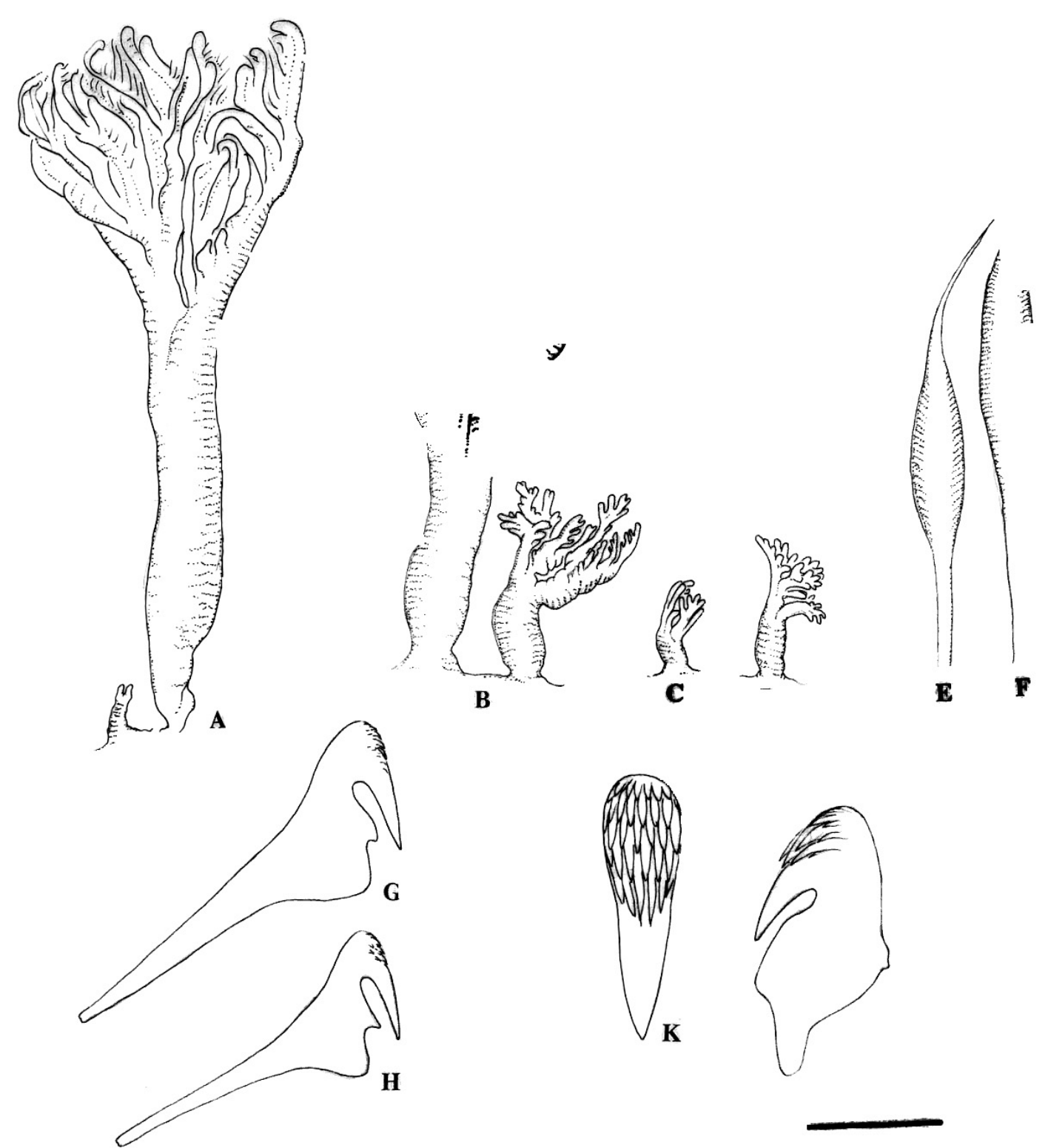

FIG. 3. - Branchia, notochaetae and uncini of Pista shizugawaensis n. sp. A and B are from paratype AMS-W29405, A, dorsal view of branchiae from chaetiger 2. B, dorsal view of branchiae from chaetiger 3. C, small-sized, $3^{\text {rd }}$ left branchia from holotype. D, small-sized, $2^{\text {nd }}$ left branchia from SAM E3457. E, F, chaetae from chaetiger 6. G-K, thoracic uncini, drawn from SEM photos. G, K, $2^{\text {nd }}$ chaetiger. H, $6^{\text {th }}$ chaetiger. I,J, $16^{\text {th }}$ chaetiger. L, abdominal uncini. Scale $1 \mathrm{~mm}$ in A-D, $50 \mu \mathrm{m}$ in E-J, $30 \mu \mathrm{m}$ in L, $25 \mu \mathrm{m}$ in K.

marked annulations, plume-shaped with a tuft of branched filaments that arise from the main stalk irregularly spirally(Figs. 2A, 3A-D, 4A, B).

Lateral lobes present on segments 2, 3, 4, 5 and 6: segment 2 with ventro-lateral lobes, fused midventrally; segment 3 with wide, semi-circular lateral lobes, discrete and not continuing dorsally or ventrally; segment 4 with small narrow lateral lobes which continues to ventral pad; and segments 5 and 6 with very small narrow lateral lobes, ventrally arranged, located between neuropodial uncinal row and ventral pad (Fig. 2B, C). Ventral pads conspicuous on thoracic chaetigers. Noticeable spherical nephridial papillae present on chaetigers 6 and 7; inserted intersegmentally, dorsal to notopodia (Fig. 2A).

Seventeen pairs of notopodia from segment 4. Notochaetae of 2 lengths, all broad-bladed, narrowwinged capillaries (Fig. 3E, F, 4C). Neuropodia from segment 5 (chaetiger 2) initially with uncini arranged in single rows, subsequently uncini in double rows from seventh uncinigerous segment to last thoracic segment; uncini arranged in single rows on abdominal tori. Uncini from anterior uncinigerous segments with well-chitinised long-handled shafts and strongly crested heads with a dental formula MF:5-6,5-6,6,7-?-?(Fig. 3G-K). Uncinal shafts pres- 

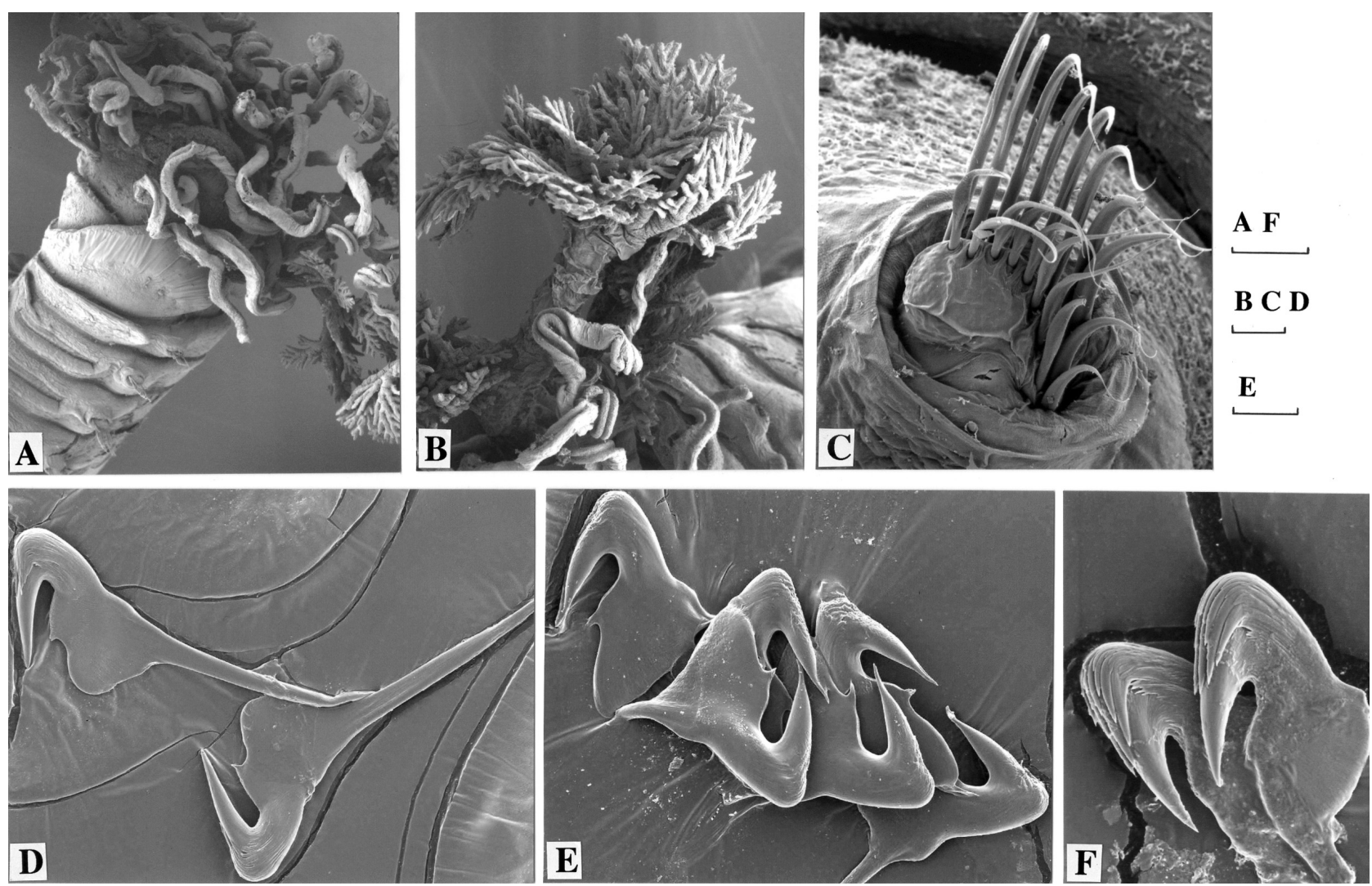

FIG. 4. - SEM photo of Pista shizugawaensis n. sp. A, lateral view of anterior part of worm, showing tentacles and branchiae. B, branchiae. C, $7^{\text {th }}$ thoracic chaetiger with chaetae. $\mathrm{D}$, middle segment $\left(6^{\text {th }}\right.$ chaetiger $)$ uncini with long handles. E, posterior segment $\left(16^{\text {th }}\right.$ chaetiger $)$ uncini with very short handle or lacking handle. F, abdominal uncini. Scale $1 \mathrm{~mm}$ in A, $0.5 \mathrm{~mm}$ in B, $50 \mu \mathrm{m}$ in C, $25 \mu \mathrm{m}$ in D and E, $15 \mu \mathrm{m}$ in F.

TABle 1. - Distribution and arrangement of branchiae in Pista shizugawaensis n. sp. Branchiae lacking (-) and 4 developmental states (undeveloped, small, middle and large) are shown.

\begin{tabular}{|c|c|c|c|c|c|c|}
\hline \multirow[t]{2}{*}{ specimen } & \multirow[t]{2}{*}{ type } & \multicolumn{2}{|c|}{ 2nd segment } & \multicolumn{2}{|c|}{ 3rd segment } & \multirow[t]{2}{*}{ remark } \\
\hline & & left & right & left & right & \\
\hline CMNH-ZW01800 & Holotype & large & large & small & middle & \\
\hline SMF-15178 & Paratype & large & - & middle & small & \\
\hline HNM-2005.1516 & Paratype & middle & middle & large & large & \\
\hline USNM-1078490 & Paratype & middle & undev. & undev. & middle & \\
\hline SAM-E3457 & Paratype & large & - & large & middle & Fig. 2 \\
\hline AMS-W.29405 & Paratype & undev. & large & middle & small & Fig. 3 \\
\hline ZMUC-POL-1851 & Paratype & small & middle & middle & middle & \\
\hline LACM-AHF-Poly 2170 & Paratype & large & - & large & undev. & \\
\hline
\end{tabular}

ent on anterior and middle thoracic chaetigers (Figs. $3 \mathrm{G}, \mathrm{H}, 4 \mathrm{D})$ but those of posterior thoracic segments are very short or lacking (Figs. 3I, J, 4E). Abdominal uncini avicular without shaft, smaller than thoracic ones (Figs. 3L, 4F).

Tube soft with incorporated sandy mud and shell fragments, usually attached to underside of a large stone or to rigid algal holdfasts, such as of Eisenia bicyclis.

Variation. Branchial size is not constant even within an individual; some branchiae lack developed filaments and some are fully developed. In Table 1, we tentatively separated the branchiae according to size and development into 4 categories, I - undeveloped (0.6-1 mm length, without filaments; Fig. 3A left), II - small (1-1.5 mm length, filaments are small and not developed; Fig. 3B right, C and D), III - middle (stalk 2-3 mm long and branched dichotomously; Fig. 3B left), IV - large (stalk long, 3-4 mm long, filaments long; Fig. 3A right). The number of pairs of branchiae is a diagnostic character of the species but the size and developmental states are not useful for identification, as shown in Table 1. We suspect that 
they are capable of regenerating branchiae if lost by predation.

Etymology. The specific name refers to the type locality, Shizugawa Bay, Sanriku Coast, Japan.

Remarks. Pista shizugawaensis n. sp. can be distinguished from other species of the genus Pista by the presence of lateral lobes on chaetigers 5 and 6 . While these lobes are small, they are clearly present on type material, thus it is unlikely that they have been missed in previous studies. Pista shizugawaensis n. sp also differs from other species of Pista described from Japan (Imajima and Hartman, 1964) and South China Sea (Hutchings, 1990)in the number and shape of branchiae, arrangement of the lateral lobes, arrangement of the nephridial papillae, dental formula and development of the shaft in anterior thoracic uncini.

In Australian waters, where the family Terebellidae has been well studied, 10 species of Pista have been reported (Hutchings and Glasby, 1988). Comparing these taxa with P. shizugawaensis n. sp., the new species resembles $P$. australis, $P$. sinusa, and $P$. curtiuncata in the number and shape of branchiae. But $P$. shizugawaensis can be distinguished from them by the morphology and arrangement of lateral lobes on segments 2-4. In the dental formula and shaft shape of uncini, $P$. shizugawaensis is similar to P. australis Hutchings and Glasby, 1988 and $P$. sinusa Hutchings and Glasby, 1988 but these characters unfortunately have not been recorded in all Pista species making it impossible to complete a comparison with all species.

\section{ACKNOWLEDGEMENT}

We acknowledge the staff of Shizugawa Nature Centrefor their help in sampling and encouragement, and Dr. Pat Hutchings and anonymous referees for their useful comments on the ms. The work is funded by Kanagawa Academy of Science and Technology (KAST).

\section{REFERENCES}

Hutchings, P.A. - 1977. Terebelliform Polychaeta of the families Ampharetidae, Terebellidae and Trichobranchidae from Australia, chiefly from Moreton Bay, Queensland. Rec. Australian Mus., 31: 1-38.

Hutchings, P.A. - 1990. Terebellidae (Polychaeta)from the Hong Kong region. In: B. Morton (ed.), Proceedings of the Second International Marine Biological Workshop: The Marine Flora and Fauna of Hong Kong and Southern China, Hong Kong, 1986. Hong Kong University Press, Hong Kong.

Hutchings, P.A. and C.J. Glasby. - 1988. The Amphitritinae (Polychaeta: Terebellidae) from Australia. Rec. Australian Mus., 40: 1-60.

Imajima, M. and O. Hartman. - 1964. Polychaetous Annelids of Japan. Occasional paper, Allan Hancock Foundation Publications, No. 26, part II, 239-452. University of Southern California Press, Los Angeles, California.

Uchida, H. - 1992. Polychaeta. In: S. Nishimura (ed.), Encyclopedia of Marine organisms. Hoikushya, Osaka. (In Japanese).

Received September 15, 2004. Accepted May 11, 2005. 